\title{
Балок и палатка - новые жилища на окраинах ненецкой ойкумены
}

\author{
Квашнин Юрий Николаевич, Институт проблем освоения Севера ТюмНЦ CO PAH; ukwa@yandex.ru
}

В статье исследованы процессы адаптации ненцев к новым типам жилищ на крайнем востоке (в междуречье Таза и Енисея) и крайнем западе (в Канинской тундре) их расселения в XX - начале XXI в. Проанализированы проблемы, с которыми сталкивались хозяйственные работники в 1930-1980-е гг., пытаясь на замену традиционному чуму внедрить в повседневную жизнь северных кочевников искусственно сконструированные палатки, кибитки, вагончики. Показаны процессы непростого, но естественного перехода тазовско-енисейских ненцев из чумов в балки долганского типа, а канинских ненцев в палатки, сконструированные коми-ижемцами. Основным выводом исследования является то, что только консервативное мышление долгое время не позволяло ненцам менять что-либо в своём жизненном укладе, в том числе типы жилища.

Ключевые слова: ненцы, Канинская тундра, Таз, Енисей, чум, юрта, балок, палатка, адаптация

\section{BALOK AND TENT — NEW DWELLINGS ON THE OUTSKIRTS OF THE NENETS OECUMENE}

Yuri N. Kvashnin, Institute of the Problems of Northern Development, Tyumen Scientific Center, Siberian Branch of the Russian Academy of Sciences; ukwa@yandex.ru;

The article examines the processes of adaptation of the Nenets to new types of dwellings in the extreme east (in the interfluve of the Taz and Yenisei rivers) and the extreme west (in the Kanin tundra) of their territory in the XX - early XXI centuries. The article analyzes the problems faced by economic workers in the 1930-1980s, trying to replace the traditional yurts by introducing artificially designed tents, wagons, and trailers into the everyday life of northern nomads. The processes of a difficult, but natural transition of the Taz-Yenisei Nenets from the yurts to the Dolgan-type gullies, and the Kanin Nenets into tents designed by the Komi-Izhemtsy are shown.

The transition of the Yenisei Nenets to the gullies might not have taken place if not for the construction of collective farms in the North in the 1930s. The Dolgans were the only nomads who lived in the gullies for almost a century before the establishment of Soviet power. None of the peoples who roamed at that time in the immediate vicinity of them replaced the traditional chums with beams. Only the attempts of Soviet workers to voluntarily improve the nomadic life of reindeer herders made this change possible. Gullies proved to be the most acceptable type of housing to replace the yurts.

The transformation of the life of the Nenets of the Kanin tundra began in the 1960s-1980s. The Komi-Izhemtsy became the innovators who radically changed the life of the Kanin reindeer breeders. A tent built in the early 1960s by the late 1980s gradually replaced the yurt. The Nenets resisted this innovation for a long time and gave up only because they saw an important advantage of the tent - the absence of the need to slaughter a large number of reindeer and to engage in labor-intensive manufacturing of skins for tires.

The main conclusion of the study is that it is only the conservative thinking that for a long time did not allow the Nenets to change anything in their way of life, including the types of dwellings.

Keywords: Nenets, Kanin tundra, Taz, Yenisei, chum, yurt, balok, tent, adaptation 
Ю. Н. КВАШНИН

\section{Введение}

Жилище является одним из важнейших элементов культуры любого народа. У народов Севера и Сибири жилища были разнообразными по типу, форме, материалам изготовления. Большое влияние на конструирование форм жилых построек оказывали географические и природно-климатические условия, приспосабливаясь к которым люди строили полуземлянки, чумы, яранги, балаганы, юрты и др. Межэтническое взаимодействие с соседними коренными и пришлыми народами нередко приводило к изменению типов кочевых жилищ или замене их на срубные постройки при переходе на оседлость.

Рассмотрению жилищ народов Севера и Сибири посвящено большое количество научных статей и монографий, а также разделов в общих этнографических описаниях конкретных этносов или регионов. Перечислить их в данной статье не представляется возможным. Можно отметить несколько капитальных трудов, где даны общая типология и классификация жилищ. Это коллективные монографии «Народы Сибири» 1956 г. и «Историко-этнографический атлас Сибири» 1961 г. (обе под редакцией М. Г. Левина, Л. П. Потапова), а также монография «Жилище народов Сибири (опыт типологии)» 1998 г., написанная 3. П. Соколовой. Изложенные в этих работах сведения позволяют проследить историческое развитие традиционных жилых построек народов Севера и Сибири, выделить общие и особенные черты. Сравнения с данными узконаправленных этнографических работ и полевых исследований позволяют увидеть изменения типов и форм жилищ у разных народов, выявить причины их перехода из чума или юрты в палатку или срубный дом. Главный вывод исследователей о жилище народов Севера и Сибири можно сформулировать словами А. А. Попова: «Народы Сибири создали жилище, которое, несмотря на относительную примитивность, показывает умение этих народов хорошо приспосабливаться к суровым северным условиям» [Левин, Потапов 1961: 131].

Одним из самых распространённых типов жилища на Севере и в Сибири была конусообразная постройка - чум ${ }^{1}$. Переносные жилища типа чума бытовали у многих коренных народов России от Кольского п-ова до низовьев р. Амур. На протяжении столетий чум оставался единственным типом жилья для большинства ненцев - кочевых оленеводов и полуоседлых рыбаков.

Описания ненецкого чума российскими и иностранными путешественниками и исследователями начиная с XVIII до начала первого десятилетия XX в. довольно однообразны: каркас из жердей, покрытый берестой или оленьими шкурами, внутри разведён огонь. Многие отмечали хорошую приспособленность устройства чума для жизни в тундре, хотя некоторые упоминали о неопрятности и нестерпимом дыме внутри него [Бруин 1873: 11-13; Лепёхин 1805: 226-227; Иславин 1847: 27-28; Шренк 1855: 286-290; Кастрен 1860: 174 -175; Кушелевский 1868: 61—62; Финш, Брэм 1882: 414 -415; Львов 1903: $8-9]$.

Советские исследователи разных профессий, работавшие в тундре и в северных посёлках в 1920 30-е гг., описывали конструкцию и внутреннюю обстановку чума ненцев по той же схеме, но без лишних эмоций [Соболев 1924: 129—130; Городков 1926: 65 - 66; Старцев 1930: 44 — 46; Гейденрейх 1930: 7—9].

Этнографы XX в. представляли в своих работах чум во всех подробностях, описывая особенности конструкции, количество оленьих шкур, необходимых для покрышек, расположение вещей внутри, способы сборки и перевозки деталей при перекочёвках, терминологию, историю развития чума [Чернецов 1936: 85-92; Хомич 1966: 101—111; Васильев, Гейденрейх 1977: 38-39].

С 1930-х гг. в журналах, посвящённых освоению Арктики и социалистическим преобразованиям на Севере СССР, а также в литературе по оленеводству начали появляться публикации о необходимости создания современного типа передвижного жилища для северных кочевников, в том числе для ненцев [Терлецкий 1932: 94-109; Виноградов 1932: 110-113; Жигунов, Терентьев 1948: 314-319]. С середины 1950-х гг. эти идеи стали развивать этнографы, когда в Институте этнографии АН СССР был создан сектор по изучению социалистического строительства у малых народностей Крайнего Севера [Файнберг 1959: 54-56; Васильев, Туголуков 1960: 139-140; Васильев, Симченко, Соколова 1966: 9-22; Хомич 1966: 282-284].

Несмотря на все усилия хозяйственных работников и учёных, проекты жилых построек, созданные в конструкторских бюро и на опытных оленеводческих станциях, не были широко восстребованы народами Севера и Сибири. Большие размеры жилищ, снижающие мобильность кочевого хозяйства, необходимость приобретения дополнительных материалов к ним, невозможность конструирования из легкодоступных природных материалов — всё это стало причинами отказа от их применения.

\footnotetext{
${ }^{1}$ Слово «чум» заимствовано из языка удмуртов, которые называли так любую конусообразную жилую или хозяйственную постройку [Квашнин 2019: 70]. В справочном издании «Народы России» оно совершенно необоснованно производится от некоего коми слова «тсом» [Тишков и др. 2008: 253].
} 
Исключением стали балки, широко распространившиеся у северных народов, живущих к востоку от Енисея, и палатки у оленеводов Канинской тундры. Первые были сконструированы русскими, вторые коми-ижемцами.

Долганский балок и его варианты у разных народов Севера описаны в этнографической литературе достаточно хорошо. Этому способствовало практически непрерывное пополнение знаний о жизни и быте народов Таймыра и близлежащих территорий различными исследователями на протяжении XIX-XX и начала XXI вв. [Миддендорф 1877: 575—576; Попов 1952: 166-172; Васильев 1963: 57, 58, 60, 61; Симченко 1970: 177; Грачёва 1994: 21-36; Дьяченко 2005: 238-241]. Нам удалось рассмотреть внешний облик и внутреннее устройство балков в экспедициях к енисейским ненцам и энцам в 2006,2009 и 2010 гг. [Квашнин 2009: 103-109; Квашнин 2011: 307].

Иная ситуация сложилась с канинскими палатками. Ленинградский этнограф Л. В. Хомич была в экспедиции на Канинском п-ове в 1958 г. до постройки там первой палатки. Все последующие экспедиции она проводила восточнее. Московский этнограф В. И. Васильев побывал на Канине в начале 1970-х гг., когда в палатках жило ещё не так много оленеводов, поэтому он их не увидел. С тех пор Канинская тундра была практически забыта этнографами. Учёными было упущено время, когда можно было зафиксировать и описать процесс перехода канинских оленеводов из чумов в палатки, который растянулся почти на тридцать лет.

В 2006-2007 гг. на Канин были организованы экспедиции студентов и преподавателей кафедры этнографии СПбГУ. Однако публикаций в виде статей или тезисов докладов, где были бы подробно описаны палатки канинских оленеводов и история их возникновения и распространения, так и не появилось. Во всяком случае, нам они не известны.

Единственной известной нам публикацией, где в сравнении с чумом оленеводов Ямала и стационарными жилищами пастухов Кольского п-ова рассматриваются канинские палатки, является статья международного коллектива авторов, опубликованная в британском научном издании "The Polar Journal" [Usenyuk et al. 2015: 170-202].

В апреле 2013 г. нам довелось побывать в канинском с. Несь, где во время проведения ежегодного праздника «Канин мэбета» («Канинские богатыри») удалось посетить оленеводческую палатку и осмотреть её устройство. Сотрудники сельской библиотеки позволили поработать с архивными материалами, касающимися жизни села и оленеводов Канинской тундры. Там мы обнаружили сведения о конструкторе первой канинской палатки.

В нашем исследовании предпринята попытка показать, что смена одного типа жилища на другой может происходить у народов Севера естественным путём. Основными задачами стали: освещение проблем, с которыми сталкивались хозяйственные работники в 1930-1980-е гг., пытаясь на замену чуму внедрить в повседневную жизнь северных кочевников новые, искусственно сконструированные типы жилищ; исследование процесса хоть и непростого, но естественного перехода восточных ненцев из чумов в балки, а западных - в палатки. В заключение поставлен вопрос о необходимости проведения новых полевых исследований для сбора более подробных сведений об истории появления и распространения балков у ненцев Тазовской и Гыданской тундр и палаток у оленеводов Канинской тундры.

\section{Где он стоял, то место почернело 2}

Удобство чума в условиях жизни в тундре и тайге доказано столетиями его использования. Он устойчив при сильном ветре. Дождевые капли и снег скатываются с его наклонной поверхности. На установку или разборку чума затрачивается чуть больше получаса. Для изготовления каркаса, покрышек, постелей, домашней утвари используются подручные материалы. Такое положение вещей в общем и целом устраивало всех до начала XX в.

В 1920-е гг. в Советском Союзе повсеместно развернулась «борьба за новый быт». Улучшение жизни северных кочевников новая власть видела в переводе их на оседлость, а при невозможности этого в усовершенствовании или замене тундрового жилища. Этнограф Г. А. Старцев писал о ненцах: «Часто кочевникам пытались втолковать об устройстве чума по-иному, в виде сферического шалаша или палатки с двумя накатами. Однако, Самоеды упорно строят свои жилища с острым концом» [Старцев 1930: 46].

Интересно, что палатки не были в новинку для народов Севера и Сибири. Они видели их у русских путешественников и исследователей XIX — начала XX в. Постепенно палатки стали входить в их обиход, а широко распространились в советское время ещё до Великой отечественной войны [Соколова 1998: 207-208]. По данным Приполярной переписи 1926-1927 гг,, опубликованным в журнале «Совет-

\footnotetext{
${ }^{2}$ Ненецкая загадка про чумовище.
} 
Ю. Н. КВАШНИН

ский Север» уполномоченным Центрального статистического управления по Дальнему Востоку П. Е. Терлецким, к тому времени в собственности тундровых и таёжных жителей от Мурманской области до Охотского моря насчитывалось 1516 палаток; при этом чумов и юрт зимних -10628 , летних -7125 , нартяных - 246. У ненцев палатки имелись только в Большеземельской тундре (473 шт.). Малоземельские, канинские ненцы и коренные народы Тобольского севера жили в чумах, в нартяных - кочевники (долганы) Туруханского края [Терлецкий 1932: 95-96, 101, 105].

Конкретное предложение по внедрению нового типа жилища для тундровиков высказал в начале 1930-х гг. некто И. В. Виноградов, опубликовав небольшую заметку, помещённую в том же журнале сразу за статьёй П. Е. Терлецкого. Палатку как замену чума он отверг сразу ввиду её неустойчивости при сильном ветре. По его словам, зимой её невозможно укрепить «потому, что земля мёрзлая..., а летом потому, что грунт очень мягок». Прежде чем предложить свой вариант, он описал тяжёлое, невыносимое, с его точки зрения, положение тундровиков, живущих в тесном, вечно задымлённом чуме, в условиях «тяжёлого санитарного быта». С некоторыми замечаниями автора, например, о конъюнктивите, ревматизме, невозможности соблюдения гигиены, можно согласиться. Другие же кажутся нам совершенно абсурдными. В частности, замечание о том, что теснота конусообразного чума заставляет женщину постоянно ходить согнувшись, даже вне чума, и такое положение влияет на конфигурацию тазовых костей [Терлецкий 1932: 110-111].

Заменой чума могла стать, по мнению Виноградова, калмыцкая кибитка (юрта). «Портативность и устойчивость кибитки по отношению к ветру не уступает чуму», - утверждал он. Для отопления жилища костёр необходимо заменить железной печкой. Войлочные покрышки заменить оленьими шкурами. Единственное, о чём придётся позаботиться кочевнику, - это приобретение железа, стекла для окон и асбеста для печной трубы. Правда, остов для кибитки «должен быть сделан специалистом», посетовал автор. Интересно, что сами ненцы в разговорах с Виноградовым говорили, что хотели бы «улучшения чума и быта в нём», однако для этого они просили лишь железные печки и брезент вместо бересты. Почему же именно калмыцкую кибитку, а не другой тип жилища пытался предложить ненцам Виноградов? А только потому, что в Тиманской тундре Ненецкого национального округа, где он в то время работал, у него под рукой оказалась, как он сам написал, всего одна книга - «Калмыки. Исследование санитарного состояния и запаса жизненных сил. Под ред. проф. Молькова» [Терлецкий: 112-113].

Поиски новых решений в конструировании жилища для кочевников продолжались и в 1940-е гг. Специалист по сельскому хозяйству Ф. Я. Гульчак в коллективном труде «Северное оленеводство», отмечая достоинства и недостатки чума, относил к последним «курное отопление, недостаточное количество света, плохую защиту от осадков, попадающих через дымовое отверстие, отсутствие пола». Конусообразность чума, по его словам, позволяет только сидеть или спать, а за низкими столами «можно только пить чай, обедать, но нельзя писать, читать». Взамен предлагался «наиболее усовершенствованный тип чума», сконструированный зоотехником Мурманской зональной оленеводческой станции Н. О. Дьяченко. Судя по фотографиям в тексте, это сооружение тоже похоже на юрту, только большую и очень громоздкую (более 5 м в высоту и около 8 м в диаметре). Для его сборки используются фанерные щиты в рост человека, деревянные шесты для остова крыши, железный конусообразный колпак для регулирования вентиляции воздуха. Покрывается такой чум оленьими нюками. Внутри сделан пол, стоят складные столы, скамейки, железная печь. Отвесные стены и достаточное количество света из окон, по мнению автора, «дают возможность поддерживать чистоту, обедать, отдыхать и работать, как в любом культурном помещении» [Жигунов, Терентьев 1948: 316-318].

В 1950 - 60-е гг. сделать более культурным быт оленеводов и охотников хотели хозяйственные работники Таймыра. Некоторые предлагали завезти в тундру разборные дома из пенопластовых плит для использования зимой, а летний чум заменить «специально изготовленными для условий севера просторными утеплёнными палатками» [Файнберг 1959: 56].

Первый опыт использования искусственно созданного тундрового жилища провело в те годы опытно-производственное хозяйство (бывшая Таймырская комплексная опытно-оленеводческая станция), располагавшееся по соседству с колхозом «Заполярник» в п. Потапово Дудинского р-на Таймырского Долгано-Ненецкого национального округа. Из Якутска был выписан один экземпляр передвижного разборного жилища «тордох» конструкции Л. Файко и И. Попова. Оно представляло собой конструкцию, похожую на якутскую юрту. Каркас диаметром около 5 м состоял из дюралюминиевых трубок. Покрытием служили оленьи нюки или брезент. Пол сделан из тонких дощечек, сбитых на ремнях. При сборке жилища их сворачивали в рулон. Основными недостатками «тордоха», по мнению работников хозяйства, были его величина и сложная система сочленений дюралюминиевых трубок, которые к тому же по углам прорывали брезент. Была отмечена и высокая стоимость этого жилища - 2800 руб. ${ }^{3}$,

\footnotetext{
${ }^{3}$ По ценам до денежной реформы 1961 г.
} 
что для северных колхозов было неподъёмной суммой [Файко 1960: 148-149; Васильев, Туголуков 1960: 140].

Помимо описанных выше было ещё несколько проектов усовершенствованного чума. В 1960-е гг. на Крайнем Севере проходил испытания чум инженера С. Р. Гринберга [Васильев, Симченко 2006: 9] и синтетическая юрта конструкции Мытищинского комбината синтетических изделий и материалов [Васильев, Симченко, Соколова 1966: 12]. Деревянная конструкция типа калмыцкой кибитки техникастроителя Г. Н. Кирпичёва использовалась в одной из оленеводческих бригад Ямальской сельскохозяйственной станции [Файко 1960: 146; Хомич 1960: 283]. В начале 1980-х гг. якутскими инженерами конструкторами Е. Н. Петровым, Н. В. Меркурьевым и В. И. Степановым было запатентовано сборноразборное здание «Север-3», напоминавшее по конструкции строительный вагончик.

Ни одна из вышеописанных конструкций не прошла испытания временем и не прижилась у народов Севера и Сибири. На наш взгляд, беда конструкторов заключалась в том, что они шли против течения, предлагая тундровым жителям под видом усовершенствований отказаться от привычного бытового уклада. При этом им предлагали покупать готовые жилища или материалы к ним. Вековой опыт строительства жилых построек в тундре и тайге отвергался почти полностью как устаревший. Имея весьма смутное представление о жизни и менталитете кочевников, конструкторы пытались перенести в тундру и тайгу своё, «городское», понимание удобного жилища. Однако для того, чтобы кочевники сами захотели сменить один тип жилища на другой, должны были сложиться определённые условия. Примером тому служит балок, прочно укоренившийся в XX в. у кочевых народов от Енисея до Лены и продолжающий сегодня своё движение на запад, к Тазовской губе.

\section{Домик на полозьях}

Балок используется сегодня в качестве зимнего передвижного жилища некоторыми долганами, северными якутами, нганасанами, энцами, восточными ненцами, а также эвенками Хантайского озера [Грачёва 1994: 22]. В коллективной монографии «Народы Сибири» балок описан как домик на полозьях, его каркас собран из деревянных реек, обтянут ярким пёстрым ситцем, сверху для тепла - покрышкой из оленьих шкур и чехлом из парусины для предохранения от сырости. В балке два застеклённых окна, железная печь, стол [Левин, Потапов 1956 746]. Подробные описания конструкции балка представлены в работах А. А. Попова [1952: 166-172], Г. Н. Грачёвой [1994: 21-36], В. И. Дьяченко [2005: 238-241].

Название «балок» происходит от северного русского слова «бо́лок» (от «болока́ть», «обола́кивать») и обозначает зимнюю повозку, крытые сани или кибитку [Даль 1880: 112].

Широкое распространение балки получили в XIX в. в Туруханском крае. Точное время появления первых образцов нами не выявлено. По данным участника Якутской комплексной экспедиции Академии наук 1925-1930 гг. ленинградского зоолога и картографа А. А. Романова, идея постройки и распространения балков принадлежала туруханским купцам, которые разъезжали по тундре со своими товарами от Енисея до Хатанги и Лены [Дьяченко 2005: 241].

Первой переняла у русских купцов балок группа населения, оформившаяся со временем в долганскую народность. По словам А. Миддендорфа, во время поездки $1842-1845$ гг. он видел в Дудине ${ }^{4}$ «небольшие деревянные шалаши, которые также назывались бо́локами. Их ставили на обыкновенные санные полозья и впрягали в них 8 сев. оленей. Они служили пастуху странствующим жилищем, которое по временам передвигалось, когда истощённое пастбище сев. оленей приходилось заменять новым» [1877: 576]. Как писал А. А. Попов, долганы называли балок сырга джие - нартяной чум [1944: 158]. На наш взгляд, более точное написание этого названия по-долгански hырга дьиэ, в переводе — «санный дом» [Аксёнова и др. 1992: 25, 63].

Балки бывали разными по величине. В одних могли поместиться два человека в лежачем положении [Кривошапкин 1865: 149], в других купцы имели возможность вести торговые сделки с тундровиками и хранить часть товара [Дьяченко 2005: 241]. Не совсем удобной, но всё же способной укрыть от непогоды повозкой называл балок А. Миддендорф [1877: 576]. Туруханский чиновник П. И. Третьяков, «утомлённый лежанкою в душном балке», с нетерпением ожидал приезда к зимовью [Третьяков 1871: 148].

В первой половине XX в., как отметила Г. Н. Грачёва, население Таймыра различало балок и санный дом (нартенный чум). Первый использовался для перевозки и хранения одежды и припасов, второй для жилья. При общем внешнем сходстве каждый из них обладал конструктивными особенностями. Главным отличием были размеры [Грачёва 1994: 24-25]. Об отличиях балка и нартенного чума по размеру и конструкции упоминал А. А. Попов [1937: 171].

${ }^{4}$ Село Дудино - современный город Дудинка, административный центр Таймырского Долгано-Ненецкого муниципального р-на Красноярского края. 
Долгое время балок оставался исключительно жилищем долган, который они использовали для перекочёвок в зимнее время. С началом коллективизации в 1930-е гг. его начали постепенно перенимать другие коренные народы Таймыра - нганасаны, эвенки, энцы и ненцы. К концу 1960-х гг. балки стали основным типом зимних жилищ большинства оленеводов и охотников почти во всех колхозах тогдашнего Усть-Енисейского р-на Таймырского национального округа [Васильев 1963: 57, 58, 60, 61; Васильев, Симченко 2006: 18; Васильев 1970: 155-156; Симченко 1970: 177].

К концу XX в., по данным В. П. Кривоногова, большинство долган уже жили оседло, поэтому традиционные виды жилища - чум и балок - сохранились в немногих семьях только в качестве временного жилища [Кривоногов 2000: 108]. Подобная ситуация сложилась и у нганасан. В настоящее время балки в качестве жилища продолжают использовать энцы и енисейские ненцы.

По данным В. И. Васильева, енисейские ненцы начали переходить в балки в середине 1930-х годов, когда в колхозе «Новая жизнь» (п. Мунгуй Мало-Хетского кочевого совета) были построены первые 11 образцов [Васильев 1970: 155-156]. В похозяйственных книгах Мало-Хетского сельского совета за 19671969 гг. у кочевых ненцев зимним жилищем записаны балки, а летним — шестовые чумы [ПМА 2009].

С 1962 г. домики-балки попытались внедрить в Ненецком округе. Проект такого жилища предложил оленеводам сотрудник Нарьян-Марской сельскохозяйственной опытной станции А. С. Пономарёв. Первый балок построили пастухи Большеземельской тундры К. А. Попов и Н. М. Ледков, перешедшие с постоянного на сменный выпас оленей. Он имел форму вагончика длиной 3,5 м, шириной 2,5 и высотой 1,8 м, установленного на специальные сани. Каркас из деревянных планок обтягивался брезентом, а зимой дополнительно чехлом из оленьих шкур. В балке была дверь и два окна. Внутри в торце балка устраивались нары в два этажа. Ближе к двери стояли железная печка и небольшой столик. Такой балок был легче и удобнее долганского балка [Хомич 1966: 261-263, 283-284; Васильев, Симченко, Соколова 1966: 16-17]. Однако эта конструкция оказалась первой и единственной в Большеземельской тундре.

Современный балок восточных ненцев представляет собой каркасное жилище из деревянных реек и дощатого пола, установленное на длинные, широкие полозья. Нижним покрытием каркаса служит клеёнка или ситец. Сверху они покрываются плотной материей или войлоком и полотнами из оленьих шкур. В балке имеется дверь и одно окно. Возле входа установлена металлическая печь-буржуйка и низкий столик для еды. У дальней стены сложены постели из оленьих шкур.

Впервые нам довелось увидеть балки у ненцев Усть-Енисейского р-на ТАО летом 2006 г. ${ }^{5}$ На стойбище ненцев Ямкиных, расположенном на берегу протоки р. Солёная, стояло три чума: два на высоком береговом уступе, ещё один - выше на материке. Чуть в отдалении от третьего чума находились три деревянных остова балков [ПМА 2006] (Рис. 1). Зимние балки мы видели на стойбищах енисейских ненцев Носковской тундры (Рис. 2), а также в посёлках Носок, Тухард и Потапово. На одном из стойбищ Носковской тундры у одной семьи кроме жилого балка (санного дома) был ещё небольшой балок для перевозки вещей и продуктов [ПМА 2009, 2010].

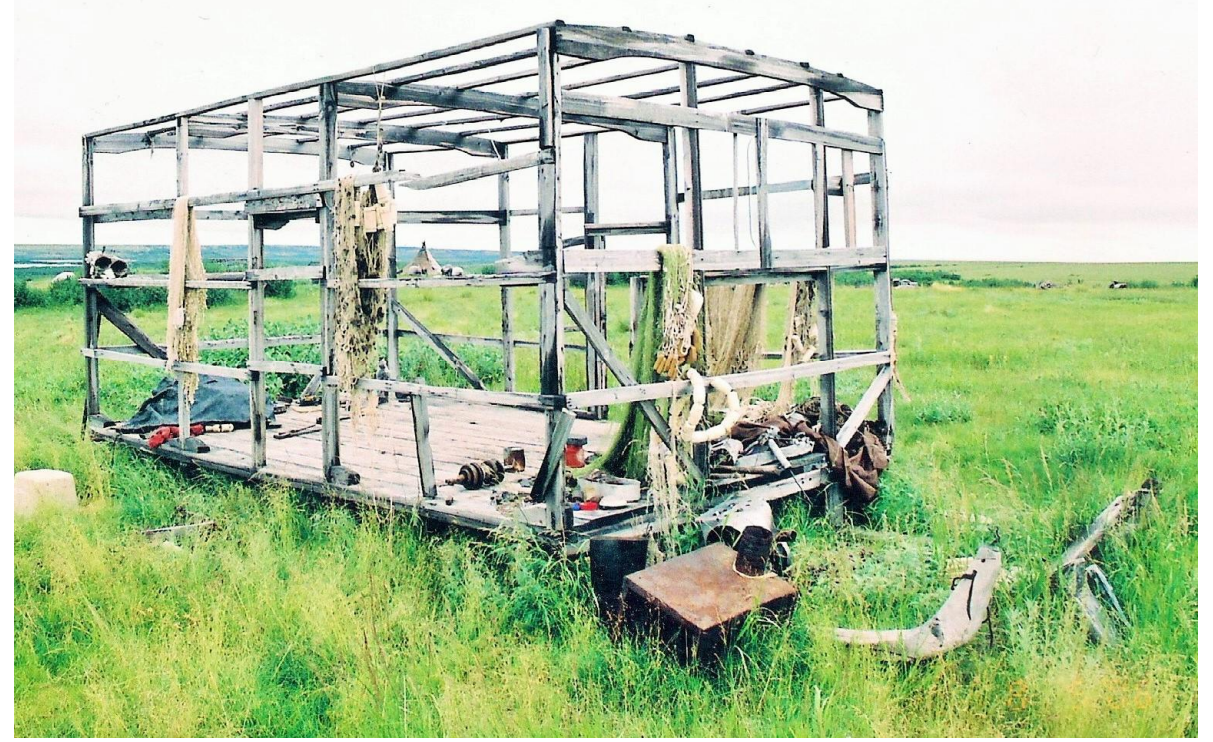

Puc. 1. Остов балка на летнем стойбище ненцев. Усть-Енисейский р-н ТАО. 2006 г. Фото Ю. Н. Квашнина

\footnotetext{
${ }^{5}$ C 1 января 2007 г. — Таймырского Долгано-Ненецкого муниципального р-на Красноярского края.
} 


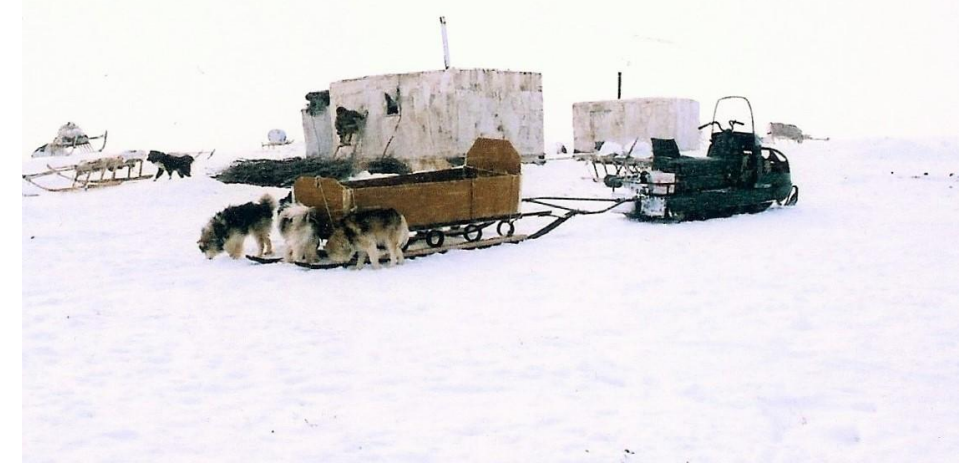

Puc. 2. Балки на зимнем стойбище ненцев. Таймырский р-н Красноярского края. 2009 г. Фото Ю. Н. Квашнина

Ближайшими соседями енисейских ненцев являются ненцы, приписанные к с. Гыда Тазовского р-на ЯНАО. Территория проживания этих групп разграничена притоком Енисея - p. Танама, что, однако, никогда не мешало оленеводам в зимне-весенний период пересекать данную границу. Ещё в 1990-е гг. нам не раз доводилось слышать от гыданских ненцев о том, что их соплеменники в Усть-Енисейском р-не зимой живут в балках. При этом они посмеивались над ними и говорили, что балки тесные и душные и что они никогда не перейдут в них жить из привычных чумов [ПМА 1993, 1995, 1996]. Весьма скептически относились к балкам и ненцы, приписанные к Тазовской поселковой администрации, называя их гробами на нартах (устное сообщение д. с.-х. н. А. А. Южакова).

Изменения отношения к балкам у ненцев Тазовского р-на стали происходить в начале 2000-х гг. Этому в определённой мере способствовало расширение территории освоения нефтегазоносных площадей на границе Тазовского р-на ЯНАО и Усть-Енисейского р-на ТАО. Нефте- и газопромыслы стали ближе к местам зимнего кочевания ненцев Гыданской и Тазовской тундр. Газовики с удовольствием обменивают у кочевников оленину и рыбу на топливо, муку, сахар и прочие товары. По словам специалистов сельских администраций, с каждым годом всё больше оленеводов-частников остаётся на зимних пастбищах за Танамой летом. Отдельные семьи оленеводов поменяли место приписки с Гыданской сельской администрации на Тухардскую ${ }^{6}$. Увеличилось количество браков между енисейскими и гыданскими ненцами. Соответственно выросло культурное влияние, которое выражалось, в том числе, в распространение балков [ПМА 2010, 2018]. В апреле-мае 2007 г. балки у ненцев-оленеводов Тазовской тундры зафиксировали участники британско-российской этнографической экспедиции М. Дуайер и К. Истомин [Попадьина 2007]. В августе 2018 г. мы отметили на одном из стойбищ гыданских ненцеврыбаков в районе фактории Развилка рядом стоящие чум и балок. Балок был покрыт войлочным покрывалом. Он использовался в качестве спальни для членов семьи. В чуме хозяева стойбища готовили пищу, ели, пили чай [ПМА 2018]. Интересно, что гыданские ненцы первое время делали в потолке посередине балка отверстие наподобие дымового отверстия в чуме (устное сообщение д. с.-х. н. А. А. Южакова).

На вопрос, чем балок лучше чума, ненцы обычно отвечают, что его не надо разбирать и собирать при перекочёвках. На наш взгляд, на этом достоинства балка заканчиваются и начинаются недостатки. Этнографы обращали на них внимание уже в начале 1930-х гг. и продолжали отмечать в 1990-е гг. [Попов 1931: 211; Грачёва 1994: 35]. Первый из них - теснота. Если в чуме может разместиться до пятнадцати человек одновременно как для принятия пищи, так и для сна, то в балке - всего от четырёх до шести человек. Второй - резкие перепады температуры. От жарко натопленной печки в балке быстро становится нестерпимо душно. Однако, как только хозяйка откроет дверь, весь жар выдувает наружу и людям, находящимся внутри балка, приходится кутаться в одежду. Процедура открывания и закрывания двери происходит неоднократно, а это может спровоцировать развитие простудных заболеваний. Третий недостаток, по нашему субъективному мнению, это санитарное состояние. Как известно, чум разбирают при перекочёвках и устанавливают на новом месте раз в три-четыре дня. При разборке все вещи, изготовленные из шкур и материи, перетряхиваются, какие-то, при необходимости, стираются. Кроме того, зимой все вещи и детали чума подвергаются воздействию холода, летом подсыхают на солнце. Всё это

${ }^{6}$ Посёлок на р. Большая Хета в Красноярском крае, один из ближайших к границе с Тазовским р-ном ЯНАО населённых пунктов. 
Ю. Н. КВАшНИН

позволяет удалить пыль, грязь, лишние запахи, не даёт возможности размножаться переносящим болезни насекомым. В балке наводить порядок с такой же периодичностью не удаётся. Перевозить его труднее, чем чум. Малооленные хозяйства вынуждены иногда впрягать в упряжку для балка беременных важенок, что может сказаться на развитии плода у них.

Несмотря на указанные недостатки, с каждым годом всё больше ненцев, кочующих в междуречье Таза и Енисея, начинают использовать балок в качестве зимнего жилища. Одна хозяйка балка из Тазовской тундры так сказала корреспонденту газеты «Советское Заполярье» ${ }^{7}$ : Раньше был чум, потом сделали балок, вдвоём с мужем тяжело чум ставить, а балок не надо собирать, шесты не надо втыкать, перевёз его и всё. Это легче, сейчас почти все в балках живут» [Герасимова 2015].

Как будет в дальнейшем развиваться ситуация с новым жилищем в этой местности, можно только предполагать. На данный момент в нашем распоряжении нет показательных данных, чтобы дать ей объективную оценку. Для сбора информации необходимо проведение новых полевых исследований.

\section{Жильё для ленивых?}

Относительно успешное распространение балка в 1960-1970-е гг. на восточной окраине проживания ненцев не привело, как было сказано выше, к его внедрению у ненцев, проживающих на других территориях. В этот период времени большинство из них продолжало жить в чумах и только на западной окраине, в Канинской тундре, начался своеобразный «палаточный ренессанс».

Вспоминая поездку на Канин в начале 1970-х гг., В. И. Васильев писал: «Мы вот уже скоро два десятка лет, как занимаемся вопросами экономики и культуры народов Крайнего Севера. За это время пришлось ознакомиться с множеством проектов жилья, которое могло бы заменить чум... В этом же Ненецком национальном округе был изобретён санный домик с покрышками из брезента. Очень хорошая вещь. Однако и тут традиция не поступилась.... Чум повсеместно позиций не сдаёт» [Васильев, Гейденрейх 1977: 37-38]. И всё-таки именно в Канинской тундре чум сдал свои позиции. В настоящее время все канинские оленеводы, как ненцы, так и коми-ижемцы, и зимой, и летом живут в палатках (Рис. 3 ).

Оленеводческая палатка сконструирована по типу армейской брезентовой шестиместной палатки. В отличие от армейской все её четыре стены укреплены фанерными щитами и деревянными рейками. Крышу каждый хозяин делает по-своему - двускатной или дугообразной. Брезент для покрытия используют и летом, и зимой, укрепляя его верёвочными стяжками. Дополнительных зимних покрышек из оленьих шкур, как для чума или балка, не требуется (Рис. 4). Внутри палатки стены и потолок обтягивают непромокаемым материалом. С одного торца у палатки низкая дверца, часто с небольшим окошком над ней. На противоположном торце - широкое окно с занавесками. У окна стоят стол и стулья. Пол покрыт досками. Слева от входа стоит печка, как правило, самодельная - из обреза бочки из-под бензина. Рядом с печкой - дрова и кухонная утварь. Дальше лежат вещи хозяев. С правой стороны на полу находятся спальные места. Они, как и в чуме, покрыты оленьими шкурами, которые расстилаются на ночь и сворачиваются утром [ПМА 2013; Usenyuk et al. 2015: 184-188].

Такую палатку сконструировали не городские конструкторы и даже не сотрудники Нарьян-Марской сельскохозяйственной опытной станции. Создателем нового типа кочевого жилья для оленеводов стал Александр Николаевич Терентьев (1928-1976), пастух колхоза «Северный полюс», коми-ижемец по национальности. Из архивных материалов библиотеки с. Несь мы узнали, что Александр Николаевич «в начале 60-х годов окончил строительные курсы в Нарьян-Маре и строил дома в д. Чижа. Но вернулся в тундру и навыки, сметку строителя применил в новом деле. Он решил сделать на замену чума разборный домик-палатку для своей семьи. Сначала летний, затем - зимний. Мысль пришла, стал подбирать шарниры, петли. Все расчёты в голове держал. Материал в лесу зимой заготовил, а весной начал строить, как задумал. На грузовые сани новые поперечины приладил, чтобы как раз все укладывалось и поехали! Для чума четыре воза требуется, а тут и двух хватит. Чум поставить три человека справятся, а палатку и один сможет. В чуме по 2-3 семьи жили, а теперь - каждой семье отдельный дом!» [ПМА 2013]. Подобные сведения, только без указания фамилии мастера, были получены Ш. Дудеком от оленеводов в Канинской тундре [Usenyuk et al. 2015: 185-186].

Нельзя сказать, что палатки сразу заменили чумы во всех хозяйствах канинских оленеводов. Поначалу их начали строить по образцу А. Н. Терентьева только его соплеменники - коми-ижемцы. Это не удивительно, потому что, в отличие от ненцев, они всегда старались сами усовершенствовать кочевой быт. К примеру, первая железная печка с трубой была установлена в 1935 г. в чуме коми-ижемца Н. 3. Чупрова, пастуха колхоза им. А. М. Горького Нижне-Печорского р-на Ненецкого округа. Его примеру затем последовали другие оленеводы [Хомич 1966: 282].

\footnotetext{
${ }^{7}$ Общественно-политическая газета Тазовского р-на ЯНАО.
} 


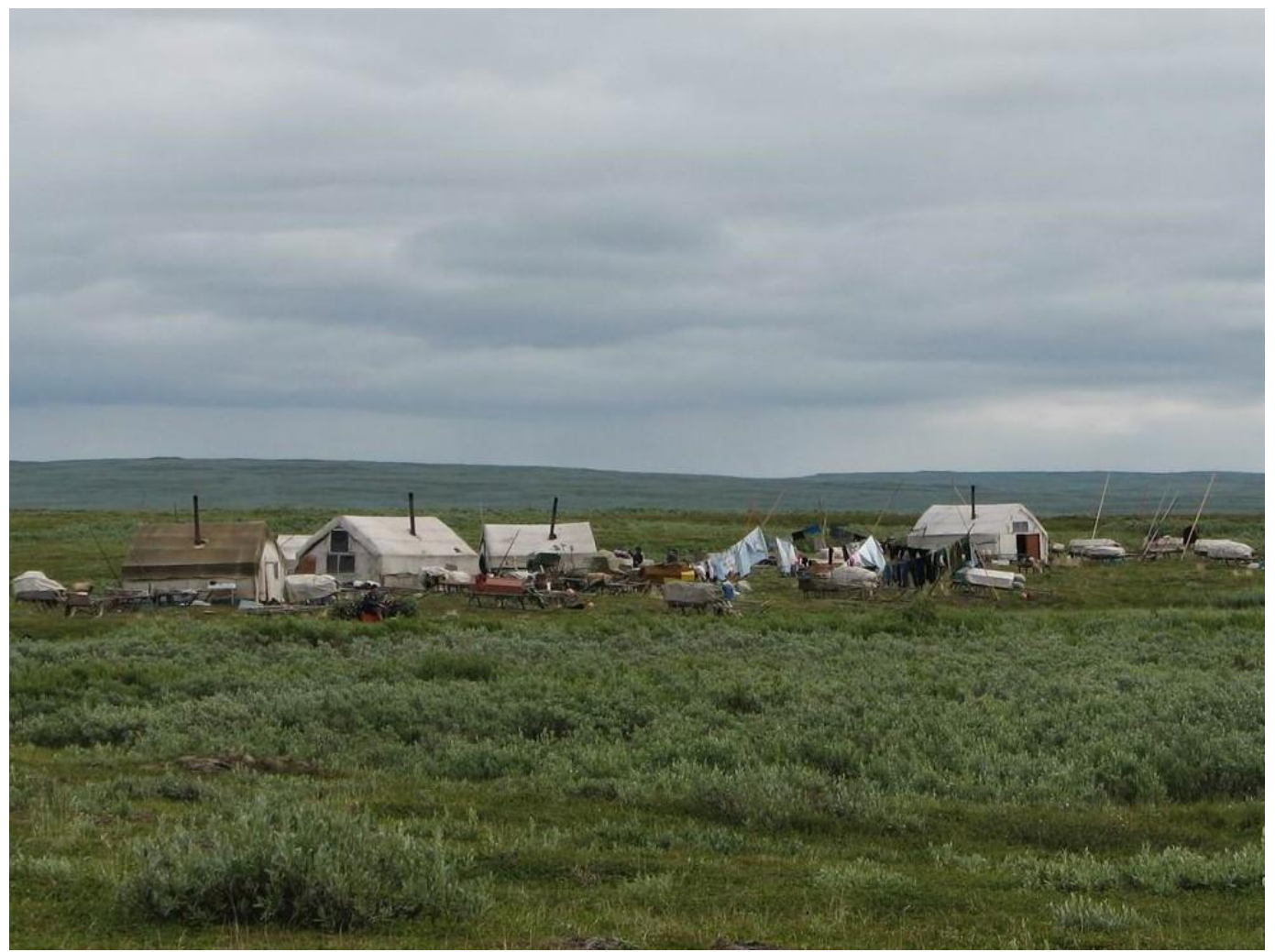

Рuc. 3. Палатки в Канинской тундре НАО. 2007 г. Фото Р. И. Сенько

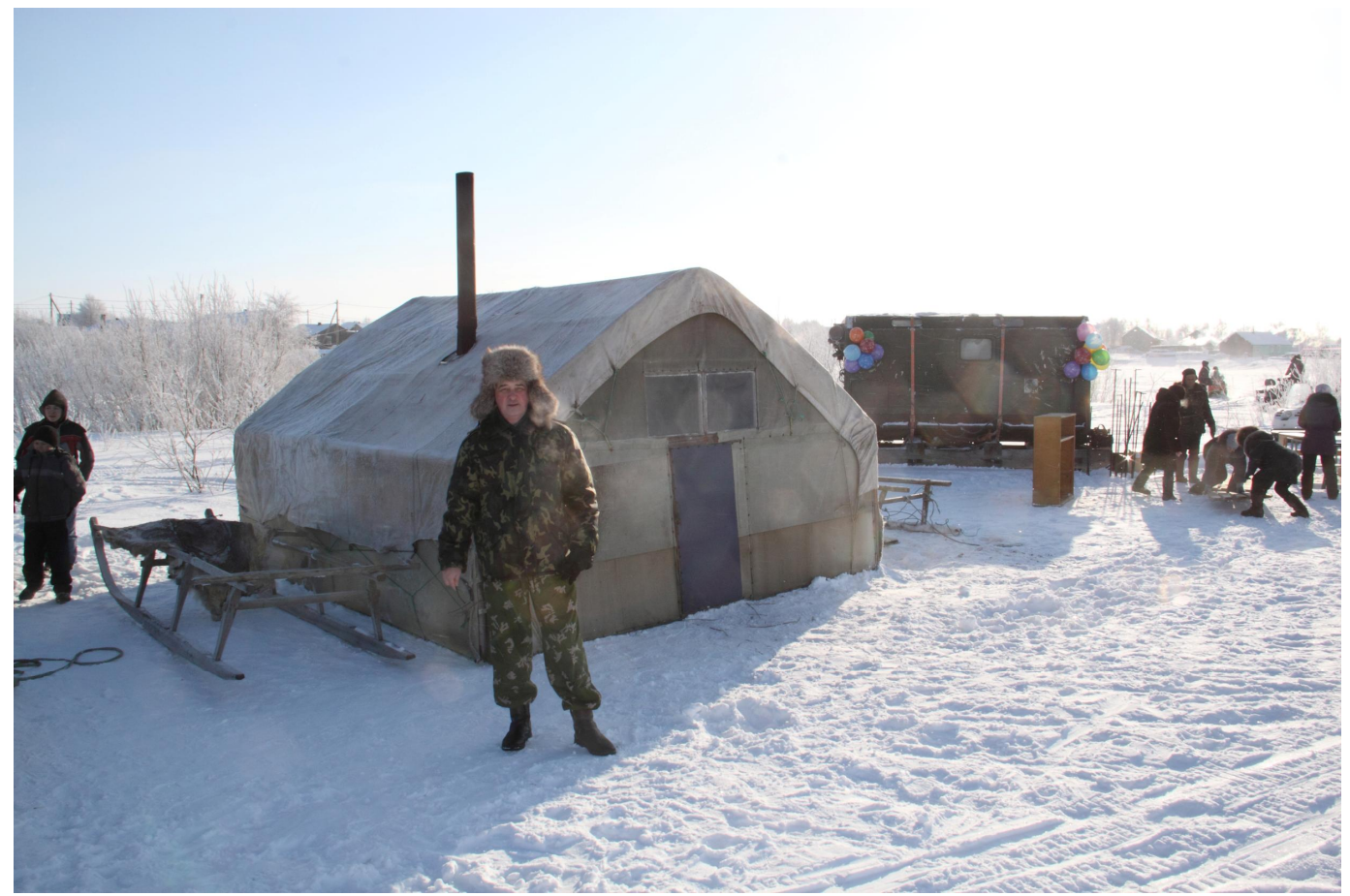

Puc. 4. Палатка канинских оленеводов в с. Несь НАО. 2013 г. Фото Р. И. Сенько

Ненцы начали переходить в палатки в начале 1970-х гг. Такой вывод приходится делать по косвенным данным, так как исследований кочевого быта канинских оленеводов в 1960-1990-е гг. этнографами практически не проводилось. Исключение составляют экспедиции Института этнографии 1974 и 1983 гг. по изучению хозяйства и культуры канинских ненцев, совершавших сезонные перекочёвки в бассейн p. Мезень. В материалах этих экспедиций наличие палаток не отмечено [Васильев 2006: 230, 235]. 
Ю. Н. КВАШНИН

Процесс перехода ненцев в палатки проходил, по всей видимости, непросто. На фотографиях конца 1970-х гг. из архива библиотеки с. Несь, где запечатлены канинские оленеводы в тундре, можно заметить интересные детали. В смешанных ижемско-ненецких оленеводческих бригадах коми-ижемцы жили в палатках, а некоторые ненцы всё ещё в чумах. Причём палатки и чумы располагались на значительном расстоянии друг от друга [ПМА 2013]. Возможно, поэтому В. И. Васильев не увидел палаток в своих поездках по Канинской тундре в начале 1970-х гг. и по Мезенскому р-ну Архангельской области в 1983 г. [Васильев, Гейденрейх 1977; Васильев 2006: 230, 235].

Сведения о бытовании палаток в Канинской тундре мы извлекли из публикаций в газете «Наръяна вындер» («Красный тундровик») ${ }^{8}$. Удалось выяснить, что одними из первых ненцев, построивших палатки в Канинской тундре, были братья Поликарп Иванович и Фёдор Иванович Латышевы. По словам дочери Поликарпа Ивановича Анны, отец построил палатку в 1973 г., отселившись со своей семьёй из чума своих родителей [Артеева 2015; Чуклин 2020]. Согласно архивным данным библиотеки с. Несь, «в конце 80-х годов в колхозе “Северный полюс" остался только один чум - у пастуха 4-й бригады И. А. Шубина. “Для музея оставили”, - шутили оленеводы» [ПМА 2013].

Удобство палатки в сравнении с чумом коми-ижемцы и ненцы оценивали по-разному. Первые говорили, что изобретателю А. Н. Терентьеву благодарны женщины, которых он избавил от выделывания вручную множества оленьих шкур для покрышек чума [ПМА 2013]. Об этом же сообщает и Ш. Дудек [Usenyuk et al. 2015: 190]. Вторые признавали, что палатка комфортнее, удобнее и намного быстрее собирается, но говорили при этом, что чум хоть и собирается дольше, но в нём просторнее. Некоторые замечали, что лёгкость является единственным достоинством палатки. Ностальгируя по чуму, отдельные ненцы называли палатку «жильём для ленивых» [Царькова 2011; Ханзерова 2013; Артеева 2015].

Главным недостатком палатки в условиях тундры была и остаётся до сих пор её неустойчивость против сильного ветра, о чём писал упоминаемый нами выше И. В. Виноградов. В 2011 г. во время урагана в Канинской тундре одну из палаток сорвало с места, она завалилась набок и перевернулась вместе с горящей печкой и хозяйкой. В результате женщина и ребенок получили тяжелые ожоги. Однако всё обошлось. Удалось вызвать санитарную авиацию и людей спасли [Торопова 2012; Ханзерова 2013].

Интересно, что о палатках в Канинской тундре знают сегодня далеко не все жители округа и его столицы Нарьян-Мара. Журналисты, впервые прилетающие на Канин, удивлённо восклицают: «Как же так? В детских книжках про тундру нам рассказывали, что для любой ненецкой семьи чум - начало всех начал. Не тут-то было: вместо чумов на Канине стоят палатки. Раз палатка, два, три. Десятки палаток» [Сущенко 2017].

Несмотря на отдельные недостатки, палатка привлекает к себе всё больше внимания оленеводов соседних тундр. Например, в Тиманской тундре, что раскинулась к востоку от Канинской, у пастухов сельскохозяйственного кооператива «Индига» палатки давно используются наряду с чумами [Торопова 2018]. Возможно, и на Тимане в обозримом будущем палатка тоже вытеснит чум.

Как видим, коми-ижемская палатка, так же как и балок, не является полноценным решением проблемы тундрового передвижного жилища. Однако достоинств у неё значительно больше. Она довольно просторная и светлая. Внутри можно стоять в полный рост и сидеть на стульях, о чём мечтали хозяйственные работники и этнографы прошлых лет. Огромным плюсом является отсутствие необходимости забивать оленей для пошива зимних покрышек из шкур. Проблемы с неустойчивостью при сильном ветре решаются довольно просто (хотя, как показывает практика, не всегда эффективно): колышки с привязанными к ним верёвочными стяжками втыкаются в землю у основания палатки. Зимой основание палатки присыпается снегом. Летом боковины палатки подпирают снаружи нартами для перевозки её деталей.

Можно согласиться с выводами о палатке Ш. Дудека. По его мнению, «вновь возникшая форма жилья - это не просто результат экспериментов с новыми типами не своих материалов и технологий, но и инструмент коллективной адаптации через локализованное, распределённое и социально встроенное творчество членов общества» [Usenyuk et al. 2015: 190].

\section{Заключение}

Подводя итог нашему исследованию, можно сказать следующее. Консервативное мышление долгое время не позволяло ненцам менять что-либо в своём жизненном укладе, будь то способы ведения оленеводческого хозяйства, одежда или жилище. В XX в. на восточной окраине расселения ненцы сменили чумы на балки, на западной - перешли в палатки. Эти изменения происходили под воздействием внешних факторов, растягиваясь на долгие годы.

\footnotetext{
${ }^{8}$ Общественно-политическая газета Ненецкого автономного округа, выходящая в г. Нарьян-Мар.
} 
На наш взгляд, переход енисейских ненцев в балки мог бы и не состояться, если бы не колхозное строительство на Севере в 1930-е гг. Единственными из кочевников, жившими в балках на протяжении почти столетия до установления советской власти, были долганы. Ни один из народов, кочевавших в то время в непосредственной близости от долган, не сменил, глядя на них, традиционных чумов на балки. Только попытки со стороны советских партийных и хозяйственных работников добровольнопринудительного улучшения кочевой жизни оленеводов сделали эту смену возможной. Балок оказался наиболее приемлемым типом жилья на замену чуму, в отличие от предлагавшихся разными конструкторами в 1930-1980-е гг. палаток, кибиток, вагончиков и пр.

Сегодня, несмотря на довольно существенные недостатки, балок продолжает завоёвывать симпатии всё большего числа ненцев в междуречье Таза и Енисея. Это обусловлено, в первую очередь, желанием хоть немного облегчить себе тяготы кочевой жизни. Определённое влияние на эти процессы, по нашему мнению, оказывает урбанистическая культура. Дом вместо чума, хоть он и на санях, меняет мироощущение человека.

Преобразование жизни и быта ненцев Канинской тундры в 1930-1960-е гг. проходило несколько иначе, чем у ненцев в низовьях Енисея, хотя и в этих краях не обошлось без попыток внедрения новых типов жилья. Новаторами, коренным образом изменившими жизнь канинских оленеводов, стали комиижемцы. Палатка, сконструированная А. Н. Терентьевым в начале 1960-х гг., к концу 1980-х гг. постепенно вытеснила чум. Консерватизм ненцев проявился и здесь. Они долго сопротивлялись этому нововведению и сдались, по всей видимости, только потому, что увидели важное преимущество палатки отсутствие необходимости забивать большое количество оленей и заниматься трудоёмким выделыванием шкур для покрышек.

Определённые проблемы для исследователей традиционного жилища ненцев создаёт сегодня недостаточность или отсутствие литературных и полевых материалов о распространении и бытовании балков у восточных ненцев и палаток у западных. Если для ненцев низовий Енисея можно, изучая научные работы, выстроить более или менее достоверную цепочку преемственности балка от долган, через нганасан и энцев, то описать процесс перехода ненцев в Канинской тундре из чумов в палатки почти невозможно. Поэтому сегодня возникает острая необходимость проведения новых полевых исследований в Тазовской, Гыданской и Канинской тундрах для сбора подробных сведений о новых типах жилища оленеводов - балках и палатках.

\section{Источники и литература}

Аксёнова и др. 1992 - Аксёнова Е. Е., Бельтюкова Н. П., Кошеверова Т. М. Словарь долганско-русский и русско-долганский. СПб., 1992. \{Aksenova E. E., Beltyukova N. P., Kosheverova T. M. Dolgan-Russian and Russian-Dolgan Dictionary. St. Petersburg, 1992.\}

Артеева 2015 - Артеева И. Из рода широколицых // Наръяна вындер. № 80 (20282). 1 августа 2015 г. // http://nvinder.ru/article/vypusk-no-80-20282-ot-1-avgusta-2015-g/8808-iz-roda-shirokolicyh. \{Arteyeva I. From the clan of broad-faced // Naryana vynder. Vol. 80 (20282). August 1, 2015 // http://nvinder.ru/article/vypusk-no-80-20282-ot-1-avgusta2015-g/8808-iz-roda-shirokolicyh.

Бруин 1873 - Бруин К. де. Путешествие через Московию Корнилия де Бруина. М., 1873. \{Bruin K. de. Travel through Moscovy by Cornelius de Bruin. Moscow, 1873.\}

Васильев 1963 - Васильев В. И. Лесные энцы (Очерк истории, хозяйства и культуры) // Труды ИЭ АН СССР. T. 84. M., 1963. C. 33-70. \{Vasilyev V. I. The Forest Enets (Essay on history, economy and culture) // Works of the IE AS USSR. Vol. 84. Moscow, 1963. P. 33-70.\}

Васильев 1970 - Васильев В. И. Ненцы и энцы Таймырского национального округа (очерк хозяйства, быта и этнических процессов, протекающих на Енисейском Севере) // Преобразования в хозяйстве и культуре и этнические процессы у народов Севера. М., 1970. С. 106-163. \{Vasilyev V. I. The Nenets and the Enets of the Taimyr National District (Essays of the economy, everyday life and ethnic processes taking place in the Yenisei North) // Economic and cultural transformations and ethnic processes among the peoples of the North. Moscow, 1970. P. 106-163.\}

Васильев 2006 - Васильев В. И. Некоторые результаты этнографических полевых работ среди ненецкого населения бассейна р. Мезень и побережья Белого моря. 1983 // Этнологическая экспертиза. Народы Севера России. 1981-1984 годы. М., 2006. С. 230-242. \{Vasilyev V. I. Some results of ethnographic fieldwork among the Nenets population of the Mezen River basin and the White Sea coast. 1983 // Ethnological expertise. Peoples of the North of Russia. 1981-1984. Moscow, 2006. Р. 230-242.\}

Васильев, Гейденрейх 1977 - Васильев В. И., Гейденрейх Л. Н. Тундра Канинская. М., 1977. \{Vasilyev V. I., Geidenreikh L. N. Tundra of Kanin. M., 1977.\} 
Васильев и др. 1966 - Васильев В. И., Симченко Ю. Б., Соколова 3. П. Проблемы реконструкции быта малых народов Крайнего Севера // Советская этнография. 1966, 3. С. 7-22. \{Vasilyev V. I., Simchenko Iu. B., Sokolova Z. P. Problems of reconstruction of the life of small peoples of the Far North // Soviet ethnography. 1966. Vol. 3. P. 7—22.\}

Васильев, Симченко 2006 - Васильев В. И., Симченко Ю. Б. Поездка в Таймырский национальный округ. 1963 г. // Этнологическая экспертиза. Народы Севера России. 1963-1980 годы. М., 2006. C. 7-14. \{Vasilyev V. I., Simchenko Iu. B. Visit to the Taimyr National District. 1963 // Ethnological expertise. Peoples of the North of Russia. 1963-1980. Moscow, 2006. P. 7-14.\}

Васильев, Туголуков 1960 - Васильев В. И., Туголуков В. А. Этнографические исследования на Таймыре в 1959 году // Советская этнография. 1960, 5. С. 128-141. \{Vasilyev V. I., Tugolukov V. A. Ethnographic studies at Taymyr in 1959 // Soviet ethnography. 1960. Vol. 5. P. 128-141.\}

Виноградов 1932 - Виноградов И. В. О замене чума более гигиеническим типом жилища // Советский Север. 1932, 3. C. 110-113. \{Vinogradov I. V. About replacing a chum with a more hygienic type of dwelling // Soviet North. 1932. Vol. 3. Р. $110-113$.

Гейденрейх 1930 - Гейденрейх Л. Канинская тундра. Архангельск, 1930. \{Geidenreikh L. Kanin tundra. Arkhangelsk, 1930.\}

Герасимова 2015 - Герасимова E. Заботы оленеводов // Советское заполярье. 27.03.2015 // http://sovzap.ru/?module=articles\&action=view\&id=4202. $\{$ Gerasimova E. Concerns of reindeer herders // Soviet Arctic. March 27, $2015 / /$ http://sov-zap.ru/?module=articles\&action=view\&id=4202. $\}$

Городков 1926 - Городков Б. Н. Краткий очерк населения Крайнего северо-востока Западной Сибири // Изв. ГРГО. Т. 58. Вып. 2. 1926. С. 50-78. \{Gorodkov B. N. A brief essay of the population of the Far North-East of Western Siberia // Bulletin of the state Russian geographical society. Vol. 58. Issue 2. 1926. P. 50-78.\}

Грачёва 1994 - Грачёва Г. Н. Передвижное жилище оленеводов Севера Западной и Средней Сибири // Памятники материальной культуры народов Сибири. СПб., 1994. С. 21-36. \{Gracheva G. N. Mobile dwelling of reindeer breeders of the North of Western and Central Siberia // Monuments of the material culture of the peoples of Siberia. St. Petersburg, 1994. P. 21-36.\}

Даль 1880 - Даль B. Толковый словарь живого Великорусского языка. Т. I. А-3. СПб.-M., 1880. \{Dal V. Explanatory Dictionary of the Living Great Russian Language. Vol. I. A-Z. St. Petersburg — Moscow, 1880.\}

Дьяченко 2005 - Дьяченко В.И. Охотники высоких широт: долганы и северные якуты. СПб., 2005. \{Dyachenko V. I. High latitude hunters: the Dolgans and the Northern Yakuts. St. Petersburg, 2005.\}

Жигунов, Терентьев 1948 - Жигунов П. С., Терентьев Ф. А. (ред.). Северное оленеводство. М., 1948. \{Zhigunov P. S., Terentyev F. A. (eds.). Reindeer husbandry of the North. Moscow, 1948.\}

Иславин 1847 - Иславин В. Самоеды в домашнем и общественном быту. СПб., 1847. \{Islavin V. The Samoyeds in the home and public life. St. Petersburg, 1847.\}

Кастрен 1860 - Кастрен М. А. Путешествие Александра Кастрена по Лапландии, северной России и Сибири (1838-1844, 1845-1849). M., 1860. \{Castren M. A. Alexander Castren's travel through Lapland, northern Russia, and Siberia (1838-1844, 1845-1849). Moscow, 1860.\}

Квашнин 2009 - Квашнин Ю. Н. Особенности развития этнических и социально-экономических процессов в низовьях Енисея в XX - начале XXI века // Вестник археологии, антропологии и этнографии. 2009, 10. С. 102 - 112. $\{$ Kvashnin Iu. N. Features of the development of ethnic and socio-economic processes in the lower reaches of the Yenisei in the $20^{\text {th }}$ - early $21^{\text {st }}$ centuries // Bulletin of Archaeology, Anthropology and Ethnography. 2009. Vol. 10. P. 102-112.\}

Квашнин 2011 - Квашнин Ю. Н. Енисейские ненцы: этнографические исследования спустя полвека // «Не любопытства ради, а познания для...» К 75-летию Ю. Б. Симченко. М., 2011. С. 283-313. \{Kvashnin Iu. N. Yenisei Nenets: ethnographic research after half a century // «Not for the sake of curiosity, but knowledge for...». To the $75^{\text {th }}$ anniversary of Iu. B. Simchenko. Moscow, 2011. P. 283-313.\}

Квашнин 2019 - Квашнин Ю. Н. О семантическом сдвиге значений слов дом, поселок, город в ненецком языке // Вестник антропологии. 2019, 1 (45). С. 67-79. \{Kvashnin Iu. N. On the semantic shift in the meaning of the words house, settlement, city in the Nenets language // Herald of Anthropology. 2019. Vol. 1(45). P. 67-79.\}

Кривоногов $2000-$ - Кривоногов В. П. К современной этнической ситуации у долган // Этнографическое обозрение. 2000, 5. С. 106-117. \{Krivonogov V. P. To the modern ethnic situation among the Dolgans // Ethnographic Review. 2000. Vol. 5. P. 106-117.\}

Кривошапкин 1865 - Кривошапкин М. Ф. Енисейский округ и его жизнь. СПб., 1865. \{Krivoshapkin M. F. Yenisei district and its life. St. Petersburg, 1865.\}

Кушелевский 1868 - Кушелевский Ю. И. Северный полюс и земля Ялмал: Путевые записки. СПб., 1868. \{Kushelevsky Iu. I. North Pole and Yalmal land. St. Petersburg, 1868.\}

Лепёхин 1805 - Лепёхин И. И. Путешествие академика Ивана Лепехина. Часть IV. В 1772 г. СПб., 1805. \{Lepekhin I. I. Travel of Academician Ivan Lepekhin. Part IV. In 1772. St. Petersburg, 1805.\}

Левин, Потапов 1956 - Левин М. Г., Потапов Л. П. (ред). Народы Сибири. М.-Л., 1956. \{Levin M. G., Potapov L. P. (ed.). Peoples of Siberia. Moscow — Leningrad, 1956.\} 
Левин, Потапов 1961 - Левин М. Г., Потапов Л. П. (ред). Историко-этнографический атлас Сибири. М.-Л., 1961. \{Levin M. G., Potapov L. P. (ed.). Historical and ethnographic atlas of Siberia. Moscow — Leningrad, 1961.\}

Львов 1903 - Львов Вл. Самоеды (очерк). M., 1903. \{Lvov Vl. The Samoyeds (essay). M., 1903.\}

Миддендорф 1877 - Миддендорф А. Ф. Путешествие на Север и Восток Сибири. Ч. ІІ. Сибирская фауна (окончание). СПб., 1877. С. 311-618. \{Middendorf A. F. Travel to the North and East of Siberia. Part II. Siberian fauna (end). St. Petersburg, 1877. P. 311-618.\}

Попадьина 2007 - Попадьина О. В Тазовской тундре полтора месяца работал этноэколог из Кембриджа. 26.05.2007 // http://www.fakt-tv.ru/report/na/203/. \{Popadyina O. An ethnoecologist from Cambridge spent a month and a half working in the Taz Tundra. May 26, 2007 // http://www.fakt-tv.ru/report/na/203/.\}

Попов 1931 - Попов А. А. Поездка к долганам // Советская этнография. 1931, 3-4. С. 210-212. \{Popov A. A. Visit to the Dolgans // Soviet ethnography. 1931. Vol. 3-4. P. 210-212.\}

Попов 1937 - Попов А. А. Охота и рыболовство у долган // Памяти В. Г. Богораза (1865-1936). М.-Л., 1937. C. 147-206. \{Popov A. A. Dolgan hunting and fishing // In memory of V. G. Bogoraz (1865-1936). MoscowLeningrad, 1937. P. 147-206.\}

Попов 1952 - Попов А. А. Кочевая жизнь и типы жилищ у долган (По материалам 1930-1931 гг.). // Сибирский этнографический сборник. I. Труды ИЭ АН СССР. Т. XVIII. 1952. С. 142-172. \{Popov A. A. Nomadic life and types of dwellings among the Dolgans (Based on materials from 1930-1931) // Siberian ethnographic collection. I. Works of the IE AS USSR. Vol. XVIII. 1952. P. 142-172.\}

Симченко 1970 - Симченко Ю. Б. Основные черты современных этнических процессов у коренного населения Авамской тундры Таймырского национального округа // Преобразования в хозяйстве и культуре и этнические процессы у народов Севера. М., 1970. С. 164-178. \{Simchenko Iu. B. The main features of modern ethnic processes among the indigenous population of the Avam tundra of the Taimyr national district // Transformations in the economy and culture and ethnic processes among the peoples of the North. Moscow, 1970. P. $164-178$.

Соболев 1924 - Соболев A. На реке Танаме // Изв. РГО. Т. 56. Вып. 2. 1924. С. 119-143. \{Sobolev A. On the Tanama River // Bulletin of the Russian Geographical Society. Vol. 56. Iss. 2. 1924. P. 119-143.\}

Соколова 1998 - Соколова 3. П. Жилище народов Сибири (опыт типологии). М., 1998. \{Sokolova Z. P. Dwelling of the peoples of Siberia (experience of typology). Moscow, 1998.\}

Старцев $1930-$ - Стариев Г. А. Самоеды (ненча): историко-этнографическое исследование Л., 1930. \{Startsev G. A. The Samoyeds (Nencha): historical and ethnographic research. Leningrad, 1930.\}

Сущенко 2017 - Сущенко A. Праздник на краю земли // Наръяна вындер. № 82 (20571). 5 августа 2017 г. // http://nvinder.ru/article/vypusk-no-82-20571-ot-5-avgusta-2017-g/18412-prazdnik-na-krayu-zemli. \{Sushchenko A. Holiday at the end of the earth // Naryana vynder. Vol. 82 (20571). August 5, 2017 // http://nvinder.ru/article/vypusk-no-82-20571ot-5-avgusta-2017-g/18412-prazdnik-na-krayu-zemli.

Терлецкий 1932 - Терлецкий П. Жилищные условия населения Крайнего Севера // Советский Север. $1932,3$. C. 94-109. \{Terletsky P. Housing conditions of the population of the Far North // Soviet North. 1932. Vol. 3. P. 94-109.\}

Тишков и др. 2008 - Тишков В. А., Журавский А. В., Казьмина О. Е. (отв. ред.). Народы России: Атлас культур и религий. М., 2008. \{Tishkov V. A., Zhuravskiy A. V., Kazmina O. E. (ex. ed.). Peoples of Russia: Atlas of Cultures and Religions. Moscow, 2008.\}

Торопова 2012 - Торопова Л. У оленеводов общины «Канин» // Наръяна вындер. 24 апреля 2012 г. // http://old.nvinder.ru/?t=sm\&d=24\&m=4\&y=2012\&n=10. \{Toropova L. At the reindeer breeders of the Kanin community $/ /$ Naryana vynder. April 24, $2012 / / \mathrm{http}: / /$ old.nvinder.ru/?t=sm\&d=24\&m=4\&y=2012\&n=10. $\}$

Торопова 2018 - Торопова Л. Равнение - на профессионалов оленеводства // Наръяна вындер. № 83 (20714). 7 августа 2018 г. // http://nvinder.ru/article/vypusk-no-83-20714-ot-7-avgusta-2018-g/33137-ravnenie-na-professionalovolenevodstva. \{Toropova L. Alignment - to the professionals of reindeer husbandry // Naryana vynder. Vol. 83 (20714). August 7, 2018 // http://nvinder.ru/article/vypusk-no-83-20714-ot-7-avgusta-2018-g/33137-ravnenie-na-professionalovolenevodstva.

Третьяков 1871 - Третьяков П. И. Туруханский край, его природа и жители. СПб., 1871. \{Tret'iakov P. I. Turukhansk region, its nature and inhabitants. St. Petersburg, 1871.\}

Финш, Брем 1882 - Фини О., Брэм А. Путешествие в Западную Сибирь. М., 1882. \{Finish O., Brem A. Travel to Western Siberia. Moscow, 1882.\}

Файко 1960 - Файко Л. И. Об усовершенствовании кочевого жилища народов Севера // Советская этнография. 1960, 2. C. 144-150. \{Faiko L. I. On the improvement of the nomadic dwelling of the peoples of the North // Soviet ethnography. 1960. Vol. 2. P. $144-150$.

Файнберг 1959 - Файнберг Л. А. Хозяйство и культура Таймырских нганасан (по материалам колхоза имени Шмидта Таймырского национального округа) // Советская этнография. 1959, 2. С. 47-60. \{Fainberg L. A. Economy and culture of the Taimyr Nganasans (based on the materials of the Schmidt collective farm of the Taimyr national district) // Soviet ethnography. 1959. Vol. 2. P. 47-60.\} 
Ханзерова 2013 - Ханзерова И. Трагедия на Канине // Наръяна вындер. № 53 (19965). 21 мая 2013 г. // http://nvinder.ru/article/vypusk-no-53-19965-ot-21-maya-2013-g/654-tragediya-na-kanine. \{Khanzerova I. Tragedy on Kanin // Naryana vynder. Vol. 53 (19965). May 21, 2013 // http://nvinder.ru/article/vypusk-no-53-19965-ot-21-maya-2013-g/654tragediya-na-kanine.

Хомич 1966 - Хомич Л. В. Ненцы. Историко-этнографические очерки. М.-Л., 1966. \{Khomich L. V. The Nenets. Historical and ethnographic essays. Moscow — Leningrad, 1966.\}

Царькова 2011 - Царькова Л. Родом с полуострова Канин // Наръяна вындер. 27 сентября 2011 г. // http://old.nvinder.ru/?t=sm\&d=27\&m=9\&y=2011\&n=9. \{Tsarkova L. Originally from the Kanin Peninsula // Naryana vynder. September 27, $2011 / / \mathrm{http}: / /$ old.nvinder.ru/?t=sm\&d=27\&m=9\&y=2011\&n=9. $\}$

Чернецов 1936 - Чернец̧ов В. Н. Чум // Советская этнография. 1936, 6. С. 85-92. \{Chernetsov V. N. Chum // Soviet ethnography. 1936. Vol. 6. P. 85-92.\}

Чуклин 2020 - Чуклин А. Наталья Латышева: Язык тундры - ненецкий // Наръяна вындер. № 23 (20937). 5 марта 2020 г. // http://nvinder.ru/article/vypusk-no-23-20937-ot-5-marta-2020-g/64010-natalya-latysheva-yazyk-tundryneneckiy. \{Chuklin A. Natalia Latysheva: The language of the tundra is Nenets // Naryana vynder. Vol. 23 (20937). March 5, 2020 // http://nvinder.ru/article/vypusk-no-23-20937-ot-5-marta-2020-g/64010-natalya-latysheva-yazyk-tundry-neneckiy. $\}$

Шренк 1865 - Шренк $А$. Путешествие к северо-востоку Европейской России чрез тундры самоедов к северным Уральским горам. СПб., 1855. \{Shrenk A. Travel to the northeast of European Russia through the Samoyed tundra to the northern Ural Mountains. St. Petersburg, 1855.\}

Usenyuk et al. - Usenyuk S., Dudeck S., Garin N. The making of a home in a changing northern context: an ethnographic account of contemporary housing practices among Russian reindeer nomads // The Polar Journal. 2015. Vol. 5. No. 1. P. $170-202$. 